\title{
Pengembangan Kreatifitas Menulis Santri Melalui Ngaji Jurnalistik Dipondok Pesantren
}

\author{
${ }^{1}$ Lutfiana, ${ }^{2} \mathrm{M}$. Arif Khoiruddin \\ IAI Tribakti Lirboyo Kediri \\ 1uphi.fiana17@gmail.com, 2arif@iai-tribakti.ac.id
}

\begin{abstract}
ABSTRAK
Karya tulis memiliki peran penting mengangkat peradaban bangsa yang merupakan jembatan antara masa lampau dengan masa sekarang dan jembatan antara orang sekarang dengan orang masa depan. Minimnya kemampuan menulis santri di pondok pesantren menjadi persoalan tersendiri, banyak santri mengaji dan membaca kitab kuning yang ditulis ulama terdahulu, namun santri bahkan kyai belum banyak menghasilkan karyakarya melalui tulisan. Melalui kegiatan pengembangan kreatifitas menulis, santri diharapkan dapat menghasilkan karya tulis yang bisa dipublikasikan melalui berbagai media untuk menjawab tantangan perkembangan zaman. Metode penelitian menggunakan pendekatan kualitatif menjelaskan pengembangan kreativitas menulis santri dipondok pesantren. Data diperoleh melalui wawancara, observasi dan dokumentasi kemudian data diolah dan dianalisis melalui reduksi data, penyajian data dan verifikasi data. Rendahnya kreatifitas menulis santri disebabkan kurangnya arahan dan bimbingan, kurang memahami konsep kaidah penulisan, terbiasa dengan sesuatu yang instan termasuk padatnya kegiatan pondok. Dengan memfasilitasi media cetak dan online sebagai sarana menyalurkan kreatifitas santri juga memberikan kegiatan ngaji jurnalistik secara berkelanjutan santri diharapkan menumbuhkan potensi menulis yang dimiliki.
\end{abstract}

Kata Kunci: Kreatifitas, Menulis, Santri, Jurnalistik

\section{PENDAHULUAN}

Pesantren merupakan lembaga pendidikan Islam di Indonesia yang ikut berperan penting dalam perkembangan keilmuan Islam dan mempersiapkan generasi muda sebagai penerus bangsa dimasa mendatang. Pesantren sebagai lembaga pendidikan dan dakwah dalam menghadapi perkembangan dan perubahan zaman, perlu membekali santri dengan kemampuan dan keterampilan sesuai dengan zamannya. Saat ini tidak bisa dipungkiri pengetahuan agama saja bagi santri masih belum cukup, perlu melakukan integrasi dan interkoneksi pengetahuan agama dan pengetahuan modern sebagai kebutuhan dalam menjawab tantangan zaman. 
Sejalan dengan perkembangan kemajuan teknologi informasi saat ini yang tengah berkembang pesat, kreatifitas dan produktifitas menulis santri penting dikembangkan di pondok pesantren guna meningkatkan kemampuan melalui beragam media termasuk media sosial dengan tujuan menyebarluaskan ajaran Islam yang menjadi kewajiban sebagai seorang muslim. Menulis merupakan bentuk kegiatan dan aktifitas seseorang dalam menuangkan gagasan melalui media bahasa. Kemampuan menggunakan struktur bahasa, kosakata dan tata tulis merupakan produktifitas dan ekspresi yang wajib dimiliki penulis. ${ }^{1}$

Kemampuan menulis adalah salah satu bagian dari ketrampilan dalam berbahasa yang ekspresif dan produktif dalam berkomunikasi secara tidak langsung bertatap muka dengan pihak lain yang merupakan gabungan dari tiga komponen yaitu gerak otak, otot dan hati yang bergerak secara sinergi. ${ }^{2}$ Perintah menulis sendiri dalam agama Islam telah tercantum dalam AlQur'an surat Al Qamar.

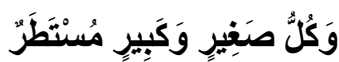

Terjemahnya : Dan segala (urusan) yang kecil maupun yang besar adalah tertulis. (Q.S Al-Qamar :ayat 53)

Menulis atau mengarang ibarat seseorang yang sedang belajar naik sepeda, harus sering berlatih agar bisa berkembang. Menulis dapat dengan mudah apabila sering berlatih dan akan menjadi sulit apabila tidak sering menulis sehingga akan bingung akan memulai dari mana. ${ }^{3}$ Dengan sering menulis maka semakin mudah dan berkualitas juga tulisannya. Niat yang kuat, banyak berlatih dan belajar serta banyak membaca merupakan tiga hal yang harus diperhatikan bagi seseorang yang ingin menguasai ketrampilan menulis. ${ }^{4}$

Pada prinsipnya kegiatan menulis dalam dunia pendidikan sangat penting yang merupakan media komunikasi secara tidak langsung. Dengan menulis dapat mendorong berfikir secara kritis, memperdalam, persepsi atau daya tanggap, dapat memecahkan persoalan yang dihadapi dan menambah pengalaman penulis. ${ }^{5}$ Tidak bisa dipungkiri bahwa karya tulis berperan besar untuk mengangkat paradaban bangsa. Bisa dikatakan bahwa karya tulis merupakan salah satu ukuran kebesaran suatu bangsa dengan banyaknya

\footnotetext{
${ }^{1}$ Burhan Nurgiyantoro, Menulis Secara Popular (Yogyakarta: BPFE, 2010), 273.

${ }^{2}$ Henry Guntur Tarigan, Menulis Sebagai Suatu Keterampilan Berbahasa (Bandung: Aksara, 2008), 3.

${ }^{3}$ H. Mahmud, "Upaya Meningkatakan Keterampilan Menulis Dengan Teknik RCG (Reka Cerita Gambar) Pada Siswa Kelas VI SDN Rengkak Kecamatan Kopang, Kabupaten. Lombok Tengah Tahun Pelajaran 2017/2018," JISIP (Jurnal Ilmu Sosial Dan Pendidikan) 1, no. 2 (24 Maret 2019): 35, https://doi.org/10.36312/jisip.v1i2.178.

4 Supemi Supemi, "Meningkatkan Kemampuan Hasil Belajar Keterampilan Menulis Eksposisi Dengan Menggunakan Media Massa Cetak Di Kelas VII SMP," Jurnal Pendidikan Tambusai 2, no. 3 (31 Agustus 2018): 3, https://doi.org/10.31004/jptam.v2i5.82.

${ }^{5}$ Tarigan, Menulis Sebagai Suatu Keterampilan Berbahasa, 22.
} 
karya tulis yang telah digoreskan para cendekiawan. Tulisan adalah jembatan antara masa lampau dengan masa sekarang, dan tulisan adalah jembatan antara orang sekarang dengan orang masa depan. ${ }^{6}$

Saat ini kemampuan menulis santri sangat minim dan merupakan persoalan tersendiri yang sering dihadapi pondok pesantren. Banyak santri mengaji dan membaca kitab kuning yang ditulis ulama terdahulu, namun saat belum banyak kitab atau karya-karya yang dihasilkan dari santri melalui tulisan. Begitu juga Pondok Pesantren Al-Mahrisuyah merupakan lembaga Pendidikan pesantren yang di dalamnya selain mempelajari kitab-kitab salaf juga menyelenggarakan pendidikan formal dari mulai tingkat dasar sampai menengah atas dengan perpaduan salaf dan formal. Santri dipondok tersebut sebenarnya memiliki keterampilan menulis, membaca, menggambar, dan lain sebagainya. Diantara santri ada yang telah memiliki keterampilan menulis namun perlu dikembangkan. Banyak santri yang memiliki potensi menulis, banyak ditemukan karangan-karangan santri dalam buku hariannya ketika diadakan pemeriksaan kamar/razia, namun potensi menulisnya belum terarah karena belum ada upaya untuk meningkatkan keterampilan menulis santri dan tidak ada sarana untuk menyalurkan idenya. ${ }^{7}$

Melihat kondisi demikian pengasuh pondok dan pengurus mencoba menfasilitasi kreatifitas santri dengan menyediakan media menyalurkan karya-karya santri dan termasuk mengadakan kegiatan ngaji jurnalistik dan pelatihan untuk pengembangan keterampulan menulis santri. Maka tujuan dalam penelitian ini mengetahui bagaimana pengembangan kreatifitas menulis santri di ponpes Al-Mahrusiyah Lirboyo Kediri.

\section{METODE PENELITIAN}

Metode penelitian menggunakan pendekatan kualitatif deskriftif yang menjelaskan pengembangan kreatifitas menulis santri melalui kegiatan ngaji jurnalistik. Penelitian ini dilakukan di Pondok Pesantren Al Mahrusiyah, beberapa tahun terakhir kegiatan jurnalistik banyak diminati santri dalam berbagai jenjang pendidikan. Peneliti berperan sebagai pengamat penuh dan kehadiran peneliti diketahui oleh subjek peneliti. Data diperoleh melalui sumber primer yaitu Direktur Ngaji jurnalistik, anggota Ngaji jurnalistik, dan santri putri Al-Mahrusiyah yang mengikuti kegiatan Ngaji jurnalistik. Sedangkan sumber skunder diperoleh melalui dokumen tertulis maupun sumber lain yang secara tidak lansung sebagai dokumen pendukung dalam penelitian ini. Prosedur pengumpulan data dilakukan melalui observasi,

\footnotetext{
${ }^{6}$ Amin Haedari dkk., Panorama pesantren dalam cakrawala modern (Jakarta: Diva Pustaka, 2004), 44.

${ }^{7}$ Siti Nur Zahro Arifah, Wawancara Pengurus Pondok Pesantren Lirboyo Al-Mahrusiyah Putri, 2 Desember 2020.
} 
dokumentasi, wawancara kemudian data diolah dan dianalisis melalui reduksi data, penyajian data dan verifikasi data.

\section{HASIL DAN PEMBAHASAN}

Kreatifitas menulis santri pondok pesantren Lirboyo Al-Mahrusiyah terbilang masih rendah dan kurang berkembang, hal ini terlihat dari karya tulis yang dihasilkan memiliki kekurangan dan belum sesuai dengan kaidah penulisan yang baik dan benar. Tidak adanya pengarahan dan bimbingan, kurangnya memahami konsep tulis menulis yang baik, terbiasa dengan sesuatu yang instan merupakan salah satu faktor penyebabnya, sedangkan menulis merupakan proses panjang dan membutuhkan latihan dan bimbingan secara khusus. ${ }^{8}$

Kegiatan menulis merupakan salah satu sarana untuk menuangkan isi hati, pikiran dalam dalam bentuk tulisan. Menulis merupakan kegiatan untuk menyatakan pikiran dan perasaan seseorang dalam bentuk tulisan yang diharapkan dapat dipahami oleh pembaca dan berfungsi sebagai alat komunikasi secara tidak langsung. Selain itu menulis dapat meningkatkan daya kritis santri dalam merespon kejadian-kejadian yang terjadi ditengah mayarakat. ${ }^{9}$

Sebenarnya santri pondok pesantren Lirboyo Al-Mahrusiyah memiliki potensi dan minat dalam menulis, namun padatnya kegiatan pondok pesantren dan kurang keseriusan santri dalam menulis, sehingga tidak dapat berkembang dengan baik. Faktor lain yang menghambat kreatifitas santri salam menulis adalah rasa malas dan minimnya waktu luang bagi santri. ${ }^{10}$ Kegiatan menulis pada prinsipnya sebagai alat komunikasi tidak langsung, menulis sangat penting bagi santri yang mampu mendorong untuk berpikir secara kritis, memudahkan memahami hubungan gagasan dalam tulisan, memperdalam daya tanggap atau persepsi, memecahkan masalah yang dihadapai, dan mampu menambah pengalaman penulis. ${ }^{11}$

Pondok pesantren Lirboyo Al-Mahrusiyah memiliki media untuk menyalurkan kreatifitas santri melalui majalah El-Mahrusy yang saat ini berganti menjadi Pers El-Mahrusy yang tidak hanya dalam bentuk media cetak, tetapi juga dikembangkan melalui media informasi online seperti Instagram, Youtube, Facebook dan Website yang dapat diakses dimanapun, kapanpun dan oleh siapapun yang saat ini memiliki lebih dari 50.700 follower.

\footnotetext{
${ }^{8}$ Dzohron Nahdlowi, Wawancara dengan Pimpinan Umum Redaksi El-Mahrusy Pondok Pesantren Lirboyo Al-Mahrusiyah, 23 Februari 2021.

${ }^{9}$ Imron Rosidi, Menulis Siapa Takut? (Yogyakarta: Kanisius, 2009), 2.

${ }^{10}$ Munawarotun, Wawancara dengan Pengurus Pondok Pesantren Lirboyo Al-Mahrusiyah, t.t.

${ }^{11}$ Tarigan, Menulis Sebagai Suatu Keterampilan Berbahasa, 22.
} 
Pers Mahrusy sendiri terbagi menjadi tiga devisi, pertama devisi media cetak, merekalah yang mempunyai kendali pada media-media cetak pers Mahrusy termasuk di dalamnya majalah El Mahrusy. Yang kedua adalah devisi wartawan, mereka yang meliput berita dan mempublikasikan event-event yang ada di pondok pesantren Al Mahrusiyah. Dan yang terakhir yaitu devisi kreatif, mereka yang bertugas untuk mengembangkan dunia kreatif jurnalistik, membuat konten-konten youtube, vidgram, dan short movie serta masih banyak lagi. ${ }^{12}$

Tujuan utama didirikannya majalah El Mahrusy adalah sebagai wadah bagi santri untuk menyalurkan kreatifitas menulis dan jurnalistik. Dengan disediakannya sarana ini, diharapkan santri bertambah semangat dalam menulis dan dapat mengembangkan keterampilan menulis yang sudah ada. Majalah El Mahrusy juga sebagai sarana untuk mempromosikan pondok Lirboyo khususnya pondok pesantren Al Mahrusiyah. Selain itu, majalah El Mahrusy juga sebagai sarana dakwah keagamaan karena dalam majalah El Mahrusy memuat rubik kupas fiqih. Memang saat ini media sosial menjadi salah satu sarana untuk menunjukkan kreatifitas dan memiliki nilai lebih bagi seseorang baik berupa tulisan, gambar, cerita, video dan lainnya. Selain bisa dikenal banyak orang, melalui media sosial seseorang bisa mendapatkan pendapatan atau keuntungan. ${ }^{13}$

Sebagai upaya meningkatkan kreatifitas dan keterampilan menulis santri, pondok pesantren Al-Mahrusiyah juga membekali santri dengan kegiatan khusus yaitu ngaji jurnalistik sebagai salah satu pengembangan skiil dan minat melalui ekstrakulikuler pondok pesantren. Melalui kegiatan ini diharapkan dapat mengembangkan sikap, potensi, keterampilan nilai-nilai keagamaan dan pengembangan nilai-nilai moral. Dalam pembelajaran ngaji jurnalistik santri juga dikenalkan ilmu-ilmu dasar dan juga sebagai awal untuk melatih santri dalam menuangkan karyanya melalui menulis.

Ngaji jurnalistik tidak hanya mempelajari tentang penulisan saja, para santri mendapat materi tentang public speaking dan teknik pembuatan komik. Kretivitas menulis santri dapat dikembangkan dengan sering-sering berlatih. Berlatih dapat dari hal yang terkecil dahulu seperti menulis cerpen, opini, karya ilmiyah dan masih banyak lagi. Keterampilan menulis itu tidaklah mudah, tetapi memerlukan pelatihan, memiliki pengalaman yang luas akan menulis, dan juga pengetahuan yang banyak. ${ }^{14}$ Asul Wiyanto dalam Supemi mengatakan bahwa untuk menguasai keterampilan menulis,

${ }^{12}$ Nahrowi, Redaktur Redaksi El-Mahrusy Pondok Pesantren Lirboyo Al-Mahrusiyah, 10 Maret 2021.

13 Cahya Nusantara, "Peran Media Sosial untuk Peningkatan Kreativitas," Jurnal Kewarganegaraan 1, no. 2 (1 Desember 2017): 38, https://doi.org/10.31316/jk.v3i2.923.

${ }^{14}$ Risca Apriliyandari and Ali Imron, "Pengelolaan Ekstrakurikuler Jurnalistik Untuk Meningkatkan Keterampilan Menulis Siswa," Manajemen Pendidikan, 24, no. 04 (2014). h, 6 . 
harus memiliki niat yang tidak biasa. Melainkan niat yang kuat. Selain itu juga harus sering berlatih. ${ }^{15}$

Sebelum mengadakan kegiatan ngaji jurnalistik tim redaksi memiliki persiapan yang matang agar tercapai tujuan yang diharapkan. Diadakannya rapat yang dipimpin oleh pimpinan umum redaksi yang biasa disebut dengan rapat pleno. Dalam rapat tersebut membahas mulai dari penentuan tema, rubrik-rubrik yang akan dibahas, pembagian tugas dan wewenang, dan rapat pleno dihadiri oleh seluruh anggota. ${ }^{16}$

Proses kegiatan Ngaji jurnalistik merupakan kegiatan dimana santri dibimbing dalam membuat karya. Mengambil istilah dari kata ngaji, kegiatan ini tidak hanya memberikan materi tentang jurnalistik, tetapi juga santri dibimbing dalam membuat karya tulis yang baik, santri tidak hanya pandai mengaji kitab saja tapi juga harus bisa ngaji jurnalistik. Para santripun sangat berantusias mengikuti acara ngaji juralistik seperti ini. Dalam kegiatan ngaji jurnalistik, tim majalah menyediakan 50 kuota pendaftaran. Untuk persyaratan mengikuti ngaji jurnalistik ini, peserta mengumpulkan karyanya masing-masing baik berupa opini, artikel, cerpen, atau karangan-karangan yang lain. Dari karya yang dikumpulkan, dapat diketahui sebatas mana keterampilan santri Al Mahrusiyah.

Kegiatan ngaji juranlistik diadakan dalam dua sesi, dalam sesi pertama, diisi dengan seminar tentang menulis agar menambah wawasan bagi santri mengenai menulis. Kemudian sesi kedua, para santri dibimbing untuk membuat karya kemudian dikumpulkan, direvisi dan diedit oleh tim majalah untuk diterbitkan dalam majalah El-Mahrusy. Dalam kegiatan ngaji jurnalistik diharapkan para santri dapat berminat untuk menulis dan mau mengembangkan kreativtas menulisnya. Williams College dalam Nugraheti Sismulyasih mengenai pembelajaran menulis, bengkel menulis merupakan kegiatan pembelajaran menulis dengan menerapkan tahapan persiapan, menyusun data tulisan, merevisi, mengedit, dan mempublikasikan. ${ }^{18}$

Sebagai kelanjutan dari kegiatan ngaji jurnalistik, tim redaksi mengadakan follow up atau pendalaman materi tentang literasi. Pada kegiatan ini, para santri dikenalkan dengan teori-teori tentang menulis. Pendalaman materi ini disampaikan oleh pimpinan umum. Dalam pertemuan selanjutnya, tim majalah akan menghadirkan seorang ahli menulis dari luar. Dari observasi yang dilakukan peneliti dalam kegiatan follow up, pimpinan umum menyiapkan materi yang akan diberikan agar kegiatan memiliki arah yang jelas. Diantara materi tersebut adalah konsep-konsep menulis, curhat

15 Supemi, "Meningkatkan Kemampuan Hasil Belajar Keterampilan Menulis Eksposisi Dengan Menggunakan Media Massa Cetak di Kelas VII SMP," Jurnal Pendidikan Tambusai 02, no. 05 (2018). h, 3.

${ }^{16}$ Ahmad Dzohron Nahdlowi, Majalah El Mahrusy, Wawancara, 22 Februari 2019, W.03.

${ }^{17}$ Luluk Mahmudiyana, Keterampilan Menulis Santri, Wawancara, 30 Januari 2019, W.02.

${ }^{18}$ Nugraheti Sismulyasih, "Peningkatan Kemampuan Membaca Dan Menulis Permulaan Menggunakan Strategi Bengkel Literasi Pada Siswa SD,” Jurnal Primary, 7, no. 1 (2018): 3. 
para santri seputar hambatan-hambatan saat menulis dan pemberian solusi dari pimpinan umum. 19

Diantara solusi yang pimpinan umum sampaikan untuk mengatasi hambatan yaitu: a). Santri diwajibkan selalu membawa buku saku dan bolpoin untuk menulis ide karena ide ada di mana-mana dan mudah hilang ketika tidak ditulis; b). Membuat pola menulis untuk mempermudah dalam menulis; c). Harus sering mencoba dan harus percaya diri; d).Memperluas pengetahuan dengan banyak membaca sehingga tidak kehabisan kosak kata dalam menulis.

Tim redaksi memiliki beberapa fungsi baik bagi anggota dari tim redaksi sebagai produsen maupun bagi para santri sebagai konsumen. Hal ini seperti yang disampaikan oleh Hisam Sam dalam tulisannya. ${ }^{20}$ Adapun fungsi bagi tim redaksi sendiri antara lain sebagai media komunikasi secara tidak langsung, Sebagai media belajar organisasi, sebagai media penyaluran dan pengembangan kreativitas menulis santri Al Mahrusiyah. Sedangkan fungsi bagi para santri atau konsumen yaitu sebagai inspirasi bagi santri untuk mengembangkan kreativitas menulis, sebagai sumber informasi dan komunikasi, sebagai penghibur, sebagai media untuk menyalurkan karya para santri.

Ngaji jurnalistik yang merupakan bagian dari kegiatan belajar menulis yang diselenggarakan dipondok pesantren Lirboyo Al-Mahrusiyah yang tujuan utamanya memberikan pemahaman dan pengetahuan tentang teori menulis, mengupas mendalam dan tuntas berbagai kendala yang dihadapi santri dalam menulis.Hal ini juga disampaikan oleh salah satu pimpinan redaksi bahwasannya Sejalan dengan era kemajuan teknologi informasi yang tengah berkembang pesat saat ini. Kegiatan ngaji jurnalistik juga dapat meningkatkan daya kritis santri dalam merespon kejadiankejadian yang terjadi ditengah mayarakaat. ${ }^{21}$

Pembelajaran ngaji jurnalistik dipondok pesantren dapat menjadi media pengembangan kreativitas menulis sebagai suatu proses, itu sangat penting untuk mengembangakan kreativitas menulis santri. Sejalan dengan era kemajuan teknologi informasi yang tengah berkembang pesat saat ini. Kegiatan ngaji jurnalistik juga dapat meningkatkan daya kritis santri dalam merespon kejadian-kejadian yang terjadi ditengah mayarakaat.

Pelatihan ngaji jurnalistik untuk mengembangkan kreativitas menulis santri. Menurut Zantina Kirana dkk, Jurnalistik adalah kegiatan menyiapkan, mencari, mengumpulkan, mengolah, menyajikan, dan menyebarkan berita

\footnotetext{
${ }^{19}$ Observasi, Madrasah Aliyah Al Mahrusiyah, 22 Februari 2020.

20 Hisam Sam, "Pengertian Dan Karakter-Kegunaan-Fungsi-Jenis Majalah," 2018, http://www.dosenpendidikan.com/teks-editorial-pengertian-tujuan-manfaat-fungsi-ciristruktur-kaidah-contoh/.

${ }^{21}$ Nahrowi, Redaktur Redaksi El-Mahrusy Pondok Pesantren Lirboyo Al-Mahrusiyah.
} 
kepada publik secara berkala melalui media. ${ }^{22}$ Dalam pelatihan ngaji jurnalistik, seseorang dapat belajar berbagai hal. Pelatihan jurnalistik dipandu oleh seorang ahli dari luar. Seorang ahli akan menyampaikan materi dengan menggunakan strategi-strategi. Hal ini bertujuan agar materi mudah dipahami. Pelaksanaan pelatihan jurnalistik mengacu pada kesepakatan antara pimpinan umum dengan para santri serta disesuaikan dengan kegiatan pondok.

Kegiatan ngaji jurnalistik selanjutnya yaitu kegiatan follou up atau kelanjutan kegitan dari ngaji jurnalistik. Kegiatan ini diisi dengan pemberian materi oleh pimpinan umum. Dalam agenda yang telah dibentuk, follow up diadakan rutin setiap hari jum'at dan disesuaikan dengan kegiatan yang ada di pondok pesantren, ngaji jurnalistik disini tidak cukup hanya di laksanakan satu hari atau dua hari saja guna untuk menyeleksi kembali dimana santri yang bener suka dan bakat dalam kepenulisan, kemudian selesai di seleksi dan dipilih beberapa orang yang benar-benar memiliki bakat dan suka dengan kepenulisan kemudian selesai menyeleksi dibuat kelas oleh tim redaksi dan setiap kelas nya diisi 10 atau 15 orang, dan sekarang sudah menjadi 4 kelas yaitu

Kelas pertama dan kedua kelas, yaitu kelas penulisan yang diadakan rutin setiap 2 minggu sekali yang nantik di dalam penulisan tersebut santri diajarkan bagaimana cara tentang penulisan, kemudian diadakan praktek setiap santri diberi tugas menulis cerpen, selesai menulis cerpen tersebut dikumpulkan dan dikoreksi oleh tim redaksi. Kadang peserta diberi tugas untuk dikerjakan dipondok pesantren agar tetep bisa belajar, jadi selain follow up mereka juga tetap bisa belajar . Dengan kegiatan ini, diharapkan para santri dapat menulis dengan mudah dan menghasilkan karya yang berkualitas.

Kelas ketiga fotografer, kelas fotografer yaitu kelas dimana santri diajarkan pemotretan, pemotretan ini sesuai fakta yang terjadi dilapangan bagaimana cara mengambil pemotretan yang benar dan baik, kemudian diberi teori pemotretan dan prakter diluar kelas dan diberi kamera oleh Tim Redaksi. Dan kelas 4ilustrasi, kelas ilustrasi disini mereka diajarkan tentang teknik menggambar. Membuat pola arsiran dan teknik membuat karikatur.

Kemudian untuk mengaplikasikan semua materi yang telah disampaikan, santri diminta untuk membuat karangan. Karangan dapat berupa apa saja. Dari karangan ini, dapat terlihat bagaimana perkembangan kreativitas menulis santri Al Mahrusiyah. Untuk karangan yang dianggap sudah cukup baik, tim redaksi menerbitkan karangan tersebut dalam majalah El Mahrusy. Tidak hanya berperan pengembangkan keterampilan menulis santri, majalah El Mahrusy juga dapat mengembangkan keterampilan menulis bagi tim majalah itu sendiri dan kompetensi tim majalah. Hal ini

${ }^{22}$ Zantina Isaura Kirana, Cecep Suryana, dan Rojudin, "Kegiatan Jurnalistik di Sekolah Menengah," Jurnal Ilmu Jurnalistik 3, no. 04 (2018): 2. 
juga dapat meningkatkan produk jurnalistik yang menjadi katarsis informasi bagi masyarakat luas. Seperti yang disampaikan oleh ilmuan Jerman, Siegfried Weishenberg dalam Andreas Harsono mengenai empat kompetensi bagi wartawan yaitu: ${ }^{23}$

1. Kompetensi professional misalnya melakukan editing, seleksi informasi, memahami informasi dasar dan sebagainya

2. Kompetensi transfer, misalnya penguasaan bahasa, presentasi informasi, berbagai genre dalam jurnalistik

3. Kompetensi teknik, misalnya komputer, internet, dan desain grafis

4. Kompetensi tingkat lanjut, misalnya pengetahuan terhadap liputan tertentu, ilmu-ilmu sosial, bahasa asing dan sebagainya.

Beberapa cara tim majalah untuk mengembangkan keterampilannya, yaitu: banyak membaca, Orang yang banyak membaca pasti akan berwawasan luas sehingga akan lebih mudah dalam mengekspresikan idenya. Membaca merupakan kunci sukses bagi orang yang ingin menjadi penulis. Tidak ada seorang penulis yang malas untuk membaca. Don't write if you don't read itulah kata-kata seorang penulis. ${ }^{24}$

Mengikuti seminar-seminar atau pelatihan, Untuk mengembangkankreativitas menulisnya, tim redaksi mengikuti seminarseminar atau pelatihan-pelatihan jurnalistik yang ada di luar pondok. Seperti seminar yang diadakan di Institut Agama Islam Tribakti Kediri dan pelatihan jurnalistik di Madrasah Santri Design Jombang. Majalah El Mahrusy menjalin kerjasama dengan tim Ekcelent Tribakti sehingga akan bertukar informasi.

Mencari pengetahuan dari internet, Di era zaman sekarang ini, dalam perkembangan teknologi yang sangat pesat, informasi di seluruh dunia dan berbagai ilmu pengetahuan dapat dengan mudah diakses. Salah satu cara pengembangan kreativitas menulis tim redaksi yaitu melalui internet. Mereka mengakses apa-apa yang belum diketahui. Tidak hanya itu saja, melalui internet juga akan mendatangkan ide untuk menulis. Seperti pendapat Dodi Mawardi bahwa salah satu yang mampu memberikan inspirasi dalam menulis yaitu dengan rajin berselancar di dunia maya. ${ }^{25}$

Mendatangkan ahli dalam menulis, untuk mengembangkan keterampilan tim redaksi dan santri Al Mahrusiyah, mendatangkan seorang ahli menulis untuk mengarahkan dan membimbing menulis. Dari sini bisa dilihat, bahwasannya teman-teman santri Al-Mahrusiyah itu sebenarnya

${ }^{23}$ Andreas Harsono, Agama Saya Adalah Jurnalisme (Yogyakarta, Indonesia: Penerbit Kanisius, 2010). H. 34.

${ }^{24}$ Rosidi, Menulis Siapa Takut?. h, 3

${ }^{25}$ Dodi Mawardi, Cara Mudah Menulis Buku Dengan Metode 12 Pas: Tip Praktis Menulis Buku Dalam 12 Pekan Untuk Mahasiswa, Pekerja, Profesional, Dan Entrepreneur (Jakarta: Raih Asa Sukses, 2009). , 75 
memiliki potensi yang sangat besar dalam dunia tulis menulis, untuk mengembangkan kreativitas menulisnya, bahkan tidak sedikit dari temanteman santri Al-Mahrusiyah yang berpengetahuan cukup luas mengenai akur menulis para penulis yang terkenal seperti buya hamka, tereliye, dan lain sebagainya.

\section{SIMPULAN}

Rendahnya kreatifitas menulis santri disebabkan kurangnya mendapat arahan dan bimbingan, kurang memahami konsep kaidah penulisan dengan baik dan benar, terbiasa dengan sesuatu yang instan termasuk padatnya kegiatan pondok pesantren. Dengan tersedianya media cetak dan online ElMahrusy dan konten yang dibangun berasal dari para santri dan pengasuh pondok pesantren, diharapkan santri dapat menyalurkan kreatifitas dan bakat yang dimiliki termasuk dalam hal menulis, selain itu kegiatan pendukung dilakukan untuk membimbingn dan mengarahkan dalam hal menulis seperti ngaji jurnalistik yang dilakukan secara berkala dan terkonsep dengan baik, mengikutkan santri dalam kegiatan seminar dan pelatihan serta mendatangkan para pakar dibidangnya.

\section{DAFTAR PUSTAKA}

Apriliyandari, Risca, dan Ali Imron. "Pengelolaan Ekstrakurikuler Jurnalistik Untuk Meningkatkan Keterampilan Menulis Siswa," Manajemen Pendidikan, 24, no. 04 (2014): 10.

Arifah, Siti Nur Zahro. Wawancara Pengurus Pondok Pesantren Lirboyo AlMahrusiyah Putri, 2 Desember 2020.

Dzohron Nahdlowi, Ahmad. Majalah El Mahrusy. Wawancara, 22 Februari 2019. W.03.

Haedari, Amin, H. S. Mastuki, M. Ishom el-Saha, dan Mojeeb el-Shirazy. Panorama pesantren dalam cakrawala modern. Jakarta: Diva Pustaka, 2004.

Harsono, Andreas. Agama Saya Adalah Jurnalisme. Yogyakarta, Indonesia: Penerbit Kanisius, 2010.

Kirana, Zantina Isaura, Cecep Suryana, dan Rojudin. "Kegiatan Jurnalistik di Sekolah Menengah.” Jurnal Ilmu Jurnalistik 3, no. 04 (2018).

Mahmud, H. "Upaya Meningkatakan Keterampilan Menulis Dengan Teknik RCG (Reka Cerita Gambar) Pada Siswa Kelas VI SDN Rengkak Kecamatan Kopang, Kabupaten. Lombok Tengah Tahun Pelajaran 2017/2018." JISIP (Jurnal Ilmu Sosial Dan Pendidikan) 1, no. 2 (24 Maret 2019). https://doi.org/10.36312/jisip.v1i2.178.

Mahmudiyana, Luluk. Keterampilan Menulis Santri. Wawancara, 30 Januari 2019. W.02. 
Mawardi, Dodi. Cara Mudah Menulis Buku Dengan Metode 12 Pas: Tip Praktis Menulis Buku Dalam 12 Pekan Untuk Mahasiswa, Pekerja, Profesional, Dan Entrepreneur. Jakarta: Raih Asa Sukses, 2009.

Munawarotun. Wawancara dengan Pengurus Pondok Pesantren Lirboyo AlMahrusiyah, t.t.

Nahdlowi, Dzohron. Wawancara dengan Pimpinan Umum Redaksi ElMahrusy Pondok Pesantren Lirboyo Al-Mahrusiyah, 23 Februari 2021.

Nahrowi. Redaktur Redaksi El-Mahrusy Pondok Pesantren Lirboyo AlMahrusiyah, 10 Maret 2021.

Nurgiyantoro, Burhan. Menulis Secara Popular. Yogyakarta: BPFE, 2010.

Nusantara, Cahya. "Peran Media Sosial untuk Peningkatan Kreativitas." Jurnal Kewarganegaraan 1, no. 2 (1 Desember 2017): 37-40. https://doi.org/10.31316/jk.v3i2.923.

Rosidi, Imron. Menulis Siapa Takut? Yogyakarta: Kanisius, 2009.

Sam, Hisam. "Pengertian Dan Karakter-Kegunaan-Fungsi-Jenis Majalah," 2018. http://www.dosenpendidikan.com/teks-editorial-pengertiantujuan-manfaat-fungsi-ciri-struktur-kaidah-contoh/.

Sismulyasih, Nugraheti. "Peningkatan Kemampuan Membaca Dan Menulis Permulaan Menggunakan Strategi Bengkel Literasi Pada Siswa SD," Jurnal Primary, 7, no. 1 (2018).

Supemi. "Meningkatkan Kemampuan Hasil Belajar Keterampilan Menulis Eksposisi Dengan Menggunakan Media Massa Cetak di Kelas VII SMP.” Jurnal Pendidikan Tambusai 02, no. 05 (2018).

Supemi, Supemi. "Meningkatkan Kemampuan Hasil Belajar Keterampilan Menulis Eksposisi Dengan Menggunakan Media Massa Cetak Di Kelas VII SMP.” Jurnal Pendidikan Tambusai 2, no. 3 (31 Agustus 2018): 1069-81. https://doi.org/10.31004/jptam.v2i5.82.

Tarigan, Henry Guntur. Menulis Sebagai Suatu Keterampilan Berbahasa. Bandung: Aksara, 2008. 
Pengembangan Kreatifitas Menulis Santri Melalui Ngaji Jurnalistik Dipondok Pesantren 